\title{
Drivers of US Bank Failures during the Financial Crisis
}

\author{
Raymond A. K. Cox ${ }^{1}$, Randall K. Kimmel ${ }^{1}$ \& Grace W. Y. Wang ${ }^{2}$ \\ ${ }^{1}$ School of Business and Economics, Thompson Rivers University, Kamloops, Canada \\ ${ }^{2}$ Department of Maritime Administration, Texas A\&M University at Galveston, Galveston, USA \\ Correspondence: Raymond A.K. Cox, School of Business and Economics, Thompson Rivers University, \\ Kamloops, British Columbia, V2C 0C8, Canada. Tel: 1-250-852-6387. E-mail: rcox@tru.ca
}

Received: June 11, 2017

Accepted: July 9, 2017

Online Published: July 18, 2017

doi:10.5539/ijbm.v12n8p19

URL: https://doi.org/10.5539/ijbm.v12n8p19

\begin{abstract}
Hundreds of banks failed during the financial crisis of 2008 to 2010 causing significant social cost and enfeebling economic growth for years following. In the aftermath of the crisis, regulators responded, as always, with new regulations, the efficacy of which is debatable. For policy makers to enact effective regulation, they must understand the true cause of bank failures during crisis periods. We study the effects of 31 variables using univariate t-tests and probit regression to determine their influence on the probability of bank failure. We find that banks failed during the 2008 to 2010 financial crisis because of choices management made to accept more risk, specifically by having higher financial leverage, investing in higher risk loans in real estate and construction and by holding less liquid assets and fewer low risk loans like single family real estate loans. That is, the cause of US bank failures during the finance crisis was poor management.
\end{abstract}

Keywords: Basel III, equity capital, financial crisis, probit analysis, problem banks

\section{Introduction}

Waves of bank failures occurred in the United States in 1907, the Great Depression (approximately 9,000 banks failed), the savings and loan (S\&L) crisis of the 1980's and early 1990's (2,320 banks and S\&Ls failed), and the financial crisis of 2008 to 2010 (322 banks failed with 25, 140, and 157 failing in the years 2008, 2009, and 2010 respectively). The complete list of failed banks from the Federal Deposit Insurance Corporation is at the website: https://www.fdic.gov/bank/individual/failed/banklist.html. Policy makers have responded with waves of regulation: the Federal Reserve Act of 1913, the Banking Act of 1933 (Glass-Steagall), the Basel accords, and the Dodd-Frank Wall Street Reform and Consumer Protection Act of 2010. There have also be countervailing waves of deregulation: the Bank Holding Company Act of 1956, the Depository Institutions Deregulation and Monetary Control Act of 1980, the Garn-St. Germain Depository Institutions Act of 1982, the Riegle-Neal Interstate Banking and Branching Efficiency Act of 1994, and the Gramm-Leach-Bliley Act of 1999. The failure of regulators to prevent banking crises and the huge social cost associated with them points to the need for an improved understanding of why banks fail.

When Lehman Brothers failed in 2008 financial markets quickly ground to a halt and banks began to fail. Our motivation for this research is to show that bank failure in the US during the financial crisis of 2008 to 2010 was driven by the operating and financial decisions of bank management. We analyze 31 variables that have been identified in the literature as being predictive of bank failure and, based on the literature, make a priori predictions regarding their influence on bank failure. We use a univariate t-test for the difference of mean values for a variety of accounting variables followed by probit analysis using models designed to identify the channels through which risk entered the banking system. We find that banks failed during the 2008 to 2010 financial crisis because of choices management made to accept more risk, specifically by having higher financial leverage, investing in higher risk loans in real estate and construction and by holding less liquid assets and fewer low risk loans like single family real estate loans. That is, the cause of US bank failures during the finance crisis was poor management.

Our contribution to the literature is to focus on the causes of US bank failures during the financial crisis of 2008 to 2010 examining a comprehensive set of macroeconomic and bank-specific financial variables. Further, we make use of both univariate analysis, and probit analysis including fixed and rolling windows. 


\section{Literature Review}

Some of the earliest attempts to understand bank failures utilize univariate ratio analysis. Secrist (1938) studies bank failures over 10 years using univariate analysis of 4 ratios and concludes that more sophisticated statistical methods would be required to predict likely bank failures. Sinkey (1974) conducts perhaps the most complete univariate study by using a matched sample of 110 problem and non-problem banks over 7 years using 44 variables representing size, the sources and uses of revenue, profitability, capital adequacy, and managerial quality. He shows that compared to non-problem banks, problem banks tend to grow more rapidly in terms of assets and liabilities without a corresponding growth in equity, leading to a declining capital position; poorer control over operating costs; an increasing reliance on loan income at the expense of other investment income; and lower loan quality.

One of the first attempts in constructing an early warning system, by Meyer and Pifer (1970), is a precursor of the logit regression method using untransformed variables. Their study concludes that failure can be predicted with reasonable accuracy for up to 2 years prior to failure, even when embezzlement or other financial irregularities contribute to the failure, but trends in the data must be considered for the model to work. Martin (1977) refines this work by employing logit regression to analyze a set of 25 ratios from four broad groups: asset risk, liquidity, capital adequacy, and earnings. He compares results with logit and discriminant analysis, finding that discriminant analysis works better when the sample size is small, but otherwise both models produce similar results. However, logit analysis provides an estimate of the probability of failure during the next 1 or 2 year period, which may be of considerable importance to bank authorities and business.

During the same period, Sinkey (1975, 1977, and 1978) and Pettway and Sinkey (1980) use multiple discriminant analysis to successfully screen for problem banks. In the 1975 study, Sinkey ran multiple discriminant analysis on 10 ratios representing asset composition, loan characteristics, capital adequacy, sources and uses of revenue, efficiency, and profitability concluding that they are "good discriminators."

This research led in 1979 to the Uniform Financial Institutions Ratings System (UFIRS) in the US which institutionalized the use of capital adequacy, assets, management capability, earnings, and liquidity (CAMEL) to evaluate the health of banks. In 1995 regulators added sensitivity to market risk as a factor to form the CAMELS rating system.

Subsequent research on early warning systems concentrates on improving the predictive power of the model or finding additional risk factors associated with bank failures. Sinkey (1977) combines discriminant analysis with a second screen based on stock market performance using a capital asset pricing model (CAPM) and confirms that the market screen performs nearly as well as discriminant analysis on financial ratios. Yeh (1996) exploits data envelopment analysis with twelve financial ratios to study the efficiency of 54 Taiwanese banks in converting inputs into outputs. Lane, Looney, \& Wansley (1986) employ a proportional hazard model (PHM) with a set of 21 financial ratios over five years and find that different variables work better when used over a one year prediction period versus a two year period. Wheelock and Wilso (2005) utilize proportional-hazard models with time-varying covariates to study which characteristics are likely to lead banks to fail. They conclude that examiner ratings (CAMELS) are significant and non-linear with downgrades being more significant than upgrades.

Kolari, Glennon, Shin, \& Caputo (2002) build a nonparametric trait recognition model that allows for complex two- and three-variable interactions between financial and accounting variables. Curry, Elmer, \& Fissel (2007) add stock market factors to financial ratios in a logit regression utilizing 6 accounting ratios, 5 market variables and 3 risk related variables. They ascertain the addition of market factors improve the predictive accuracy of the model.

Gunsel (2010) concludes that low asset quality, low liquidity, and high credit extended to the private sector explain the survival time of banks in North Cyprus. Jin, Kanagaretnam, \& Lobo (2011) show that adding audit quality variables improves their ability to predict failures during the 2008 financial crisis. Fayman and $\mathrm{He}$ (2011) present evidence that the addition of a prepayment risk variable to regression models can improve their ability to explain bank performance measures, probably through its effect on return on loans, return on equity, and the ratio of real estate loans to total loans. Cole and White (2012) demonstrate that the traditional CAMELS proxies and measures of commercial real estate investments explain the failure of US banks in 2009, but that residential mortgage-backed securities do not.

Off-balance-sheet special purpose vehicles with implicit or explicit recourse contributes to overhanging loans for the sponsoring institutions (Gorton and Souleles, 2007; Brunnermeier and Pedersen, 2009; Shleifer and Vishny, 2010). Easy access to capital markets leads banks to rely ever more heavily on non-deposit short term funds, but 
as Acharya and Viswanathan (2011) illustrate, an adverse asset shock can quickly cause the market to dry up leaving banks scrambling to liquidate assets. This can wipe out the banks' capital leading to failure (Adrian and Shin, 2009; Brunnermeier and Pedersen, 2009; Shleifer and Vishny, 2010). Banks that have access to loan sales tend to have riskier assets leading to instability (Cebenoyan and Strahan, 2004 and Wagner, 2007). Uzun and Webb (2007) analyze the differences between banks that securitize and those that do not, concluding that large banks are more likely to securitize assets and that the extent of overall securitization is negatively related to the bank's capital ratio. However, Battaglia and Mazzuca (2014) ascertain that securitization improves Italian banks' liquidity position while it improves their credit risk position only during the 2007-2009 financial crisis.

\section{Methodology}

Martin (1977) wanted to use a probit model to predict bank failure, but "computational difficulties" forced him to use the similar logit model instead. Fortunately advances in estimation algorithms and computational power have overcome most of these difficulties and probit analysis has become a common tool in investigating bank fragility and failure (Abrams and Huang, 1987, Ioannidou and Penas, 2010, Cole and Gunther, 1998, Nier, 2005, Luccheta, 2007, Jin, Kanagaretnam, \& Lobo, 2011, Battaglia and Mazzuaca, 2014, and van Loon and de Haan, 2015). All of these studies demonstrated a different set of operating and risk characteristics leading to bank failures dependent on the time period or country. Moreover, the results of these authors show that CAMELS ratings of onsite examiners are dynamic and quickly become out-of-date.

Our study uses the probit model following Martin (1977), Abrams and Huang (1987) and Wooldridge (2006). The dependent variable is binary, coded one for banks that fail during the period and zero for banks that do not fail during the period. The probability that a bank will fail during the period can be modeled by

$$
P\left(Y_{i}=1 \mid \vec{x}\right)=G\left(\beta_{0}+\beta_{1} \vec{x}_{1}+\cdots+\beta_{k} \vec{x}_{k}\right)
$$

where $i=1, \ldots, \mathrm{K} ; x_{i}$ are the full set of explanatory variables; $\beta_{i}$ are the corresponding constants estimated from the sample data; $\mathrm{G}$ is the standard normal cumulative distribution function taking on values between zero and one for all real numbers $z$, and vectors are denoted by an $\overrightarrow{\operatorname{arrow}}$.

$$
G(z)=\Phi(z) \stackrel{\text { def }}{=} \int_{-\infty}^{z} \phi(v) d v,
$$

where $\varphi(z)$ is the standard normal density

$$
\phi(z)=(2 \pi)^{-1 / 2} \exp \left(-z^{2} / 2\right)
$$

To understand the effect of the explanatory variables, $x_{i}$, on the probability of bank failure,

$$
P\left(Y_{i}=1 \mid \vec{x}\right),
$$

we cannot look at the $\beta$ coefficients themselves as we can with OLS, but must examine the marginal (partial) effect of small changes in the $x_{i}$. If $x_{i}$, is a roughly continuous variable, its marginal effect on

$$
p(\vec{x})=P\left(Y_{i}=1 \mid \vec{x}\right)
$$

is obtained from the partial derivative:

$$
\frac{\partial p(\vec{x})}{\partial \vec{x}_{i}}=g\left(\beta_{0}+\vec{x} \vec{\beta}\right) \beta_{i}
$$

Where

$$
g(z) \stackrel{\text { def }}{=} \frac{d F}{d z}(z)
$$

$G$ is the cumulative distribution function of a continuous random variable, so $g$ is a probability density function, and since $G$ is strictly increasing, $g(z)>0$ for all $z$. Since the marginal effect of $x_{i}$ on $p(\vec{x})$ depends on $\vec{x}$ through the positive quantity $g\left(\beta_{0}+\vec{x} \vec{\beta}\right)$, the marginal effect always has the same sign as $\beta_{i}$. The marginal effects for a binary explanatory variable would be

$$
G\left(\beta_{0}+\beta_{1}+\beta_{2} x_{2}+\cdots+\beta_{K} x_{K}\right)-G\left(\beta_{0}+\beta_{2} x_{2}+\cdots+\beta_{K} x_{K}\right)
$$

and if the explanatory variable is discrete ( $x_{k}$ going from $c_{k}$ to $\left.c_{k}+1\right)$ the marginal effect would be

$$
G\left[\beta_{0}+\beta_{1} x_{1}+\beta_{2} x_{2}+\cdots+\beta_{K}\left(c_{K}+1\right)\right]-G\left(\beta_{0}+\beta_{1} x_{1}+\beta_{2} x_{2}+\cdots+\beta_{K} c_{K}\right) .
$$

To estimate the model we use maximum likelihood estimation (MLE) where the density of $y_{i}$ given $\vec{x}_{i}$ is written as

$$
f\left(y \mid x_{-} i ; \beta^{\vec{\prime}}\right)=\left[G\left(x_{-} i \beta^{\overrightarrow{ }}\right)\right]^{\wedge} y\left[1-G\left(x_{-} i \beta^{\overrightarrow{ }}\right)\right]^{\wedge}(1-y), y=0,1 .
$$

The log-likelihood function is the log of Equation 1: 


$$
\ell_{i}(\vec{\beta})=y_{i} \log \left[G\left(\vec{x}_{i} \vec{\beta}\right)\right]+\left(1-y_{i}\right) \log \left[1-G\left(\vec{x}_{i} \vec{\beta}\right)\right]
$$

The log-likelihood is obtained by summing Equation 11:

$$
\mathcal{L}(\vec{\beta})=\sum_{i=1}^{n} \ell_{i}(\vec{\beta}) .
$$

The MLE of $\vec{\beta}$, denoted by $\hat{\vec{\beta}}$, maximizes the log-likelihood. The likelihood ratio statistic is twice the difference in the log-likelihoods:

$$
L R=2\left(\mathcal{L}_{u r}-\mathcal{L}_{r}\right)
$$

where $\mathcal{L}_{u r}$ is the $\log$-likelihood value for the unrestricted model and $\mathcal{L}_{r}$ is the log-likelihood value for the restricted model.

The goodness of fit from the OLS regression estimation that calculates the proportion of the total variability in the dependent variable that is predicted by the model is likely to be very low because the predicted value of the dependent variable is a probability but the actual value is either 0 or 1 (Baltagi, 1998, and Baltagi, 2001). Several pseudo R-squared measures have been proposed. McFadden (1974) suggests the measure $1-\mathcal{L}_{u r} / \mathcal{L}_{0}$, where $\mathcal{L}_{u r}$ is the log-likelihood function for the estimated model and $\mathcal{L}_{0}$ is the log-likelihood function in the model with only an intercept. Efron(1978)proposes:

$$
R^{2} \stackrel{\text { def }}{=} 1-\frac{\sum_{i=1}^{n}\left(y_{i}-\widehat{\pi}_{i}\right)^{2}}{\sum_{i=1}^{n}\left(y_{i}-\bar{y}_{i}\right)^{2}}
$$

where $\hat{\pi}$ is the model-predicted probabilities and $\bar{y}$ is the mean of the dependent variable. We also report the Akaike information criterion (AIC) (as reported by Stata) and the Bayesian information criterion (BIC) (as reported by Stata) from the maximum likelihood estimation to aid in comparing model fit.

\section{Data and Hypotheses}

All of the data used in this study comes from the Federal Deposit Insurance Corporation (FDIC), except for home price index seasonal adjusted and growth of personal income, which come from the Federal Housing Finance Agency and the Bureau of Economic Analysis respectively. Data for the univariate analysis as well as for use as independent variables in the regression models comes from the Bank Data \& Statistic under Industry Analysis compiled by the FDIC from quarterly financial statements between 2005 and 2008. The FDIC lists 322 banks which failed during the 2008 through 2010 period.

Table 1 provides a brief description of each variable, our a priori hypotheses for these variables, and our rationale for the hypothesis. Table 2 reports the correlations between all of the variables used in this study. Few of the variables have correlation coefficients greater than 0.5 (or less than -0.5), suggesting that multicollinearity is unlikely to be a problem. To test this further we ran collinearity diagnostics for each of the models. The results for model 1 are shown in Table 3. Results for the other models were similar and are not reported. The variance inflation factor (VIF) is less than 2 in each case, a strong indication that the models do not suffer from

\begin{tabular}{|c|c|c|c|}
\hline Variable & Description & Expected Sign & Rationale \\
\hline ciloan & $\begin{array}{l}\text { commercial } \\
\text { and } \\
\text { industrial } \\
\text { loans to } \\
\text { total assets }\end{array}$ & uncorrelated & Like comm_real. \\
\hline mul_family & $\begin{array}{l}\text { multifamily } \\
\text { residential } \\
\text { real estate } \\
\text { loans to real }\end{array}$ & uncorrelated & People continue to have a need for housing in meltdowns and recession. \\
\hline
\end{tabular}
multicollinearity (the most common rule of thumb is a VIF greater than 10 merits further investigation, though O'Brien (2007) cautions that even higher VIFs do not invalidate the regression results.)

Table 1. Variables Descriptions and Hypotheses for effect on the probability of bank failure 
estate loans

sig_family

1-4 family

uncorrelated

residential

loans to real

estate loans

trade ast

brokdep

chargeoff net charge

comm_real_commercial

cons_devlp construction

foreclosure real estate

loanast Total loans

loansale net gains on

lossallow loan loss

pastdue

capital trading

account

assets to

total assets

brokered

positive

deposits to

total

deposits

offs to

average

loans

real estate

loans to real

estate loans

and land

developmen

$t$ loans to

real estate

loans

acquired

through

foreclosure

to total

assets

to total

assets

sales of

loans to

total

non-interest

income

allowance

tota

loans

non-perfor

ming loans

to total

assets

positive

uncorrelated

positive

positive

positive

positive

positive

positive

positive

equity

negative
Similar to mul_family.

Assets owned by customers.

This is hot money from brokers raising deposits from high interest certificates of deposit indicative of a high risk bank.

This is the recognised bad debt experience.

These assets are income-producing properties focusing on financing commercial real estate developers. They are sensitive to economic downturns.

These are risky assets sensitive to the business cycle.

This is the process to repossess the security (houses) pledged for loans.

The higher the level of loans and lease financing receivables to total assets, the safer the bank's portfolio.

Banks that are selling their loans are in need of liquidity which is connected with poor operating performance.

Reflects expected bad debt expense.

Similar to chargeoff

The higher this ratio the greater financial strength and ability to weather the storm in dire times. 
total assets

cash

cash and negative
due from
depository
institutions
to total
assets

debt_sec

total

negative

short-term

debt

security to

total assets

deploan

loans to

depository

institutions

to total

assets

idloan

loans to

negative

individuals

to total

assets

insureddep Insured

negative deposits to

total

deposits

interbank

interbank

deposits to

total

deposits

loangrowth growth of

total loans

and leases

MBS

mortgage-ba

cked

securities to

total assets

non_incom non-interest

e

income to

total income

off-bal

off-balance

sheet

derivatives

to total

assets

realloan real estate

loans to

total assets

roa

return on negative

assets

sec_asset securities to negative

total assets
If this ratio is too low it implies illiquidity.

These include government securities owned.

These are assets to high-quality institutions.

These loans include credit cards whose risk can be micromanaged with the credit limits and short maturity coupled with high income from interest and fees.

The greater the percentage of insured deposits the lower the number of high-value deposits being monitored by their owners leading to lower market discipline.

Presumably banks monitor the default risk of the banks they deposit in. Thus, a high inter bank is associated with confidence of other banks in the risk of the deposit bank.

High loan growth rates typically indicate higher credit risk. However, once the economy has entered into a crisis weaker banks susceptible to failure will abandon loan growth.

As stated in the literature, before this crisis MBS were viewed as gilt-edge assets. On the other hand, MBS is of long duration exposing the holder to interest rate risk and heavy losses if rates increase. However, typically in financial crisis regulators combat the calamity by injecting liquidity and decreasing interest rates.

This variable generates a more stable income stream from sources other than securities and loans.

Normally sophisticated banks engage in derivatives.

Prior to the housing asset bubble bursting in the time period of this study loans secured by real estate were considered to be safe, secured by a mortgage on a consumer's primary residence.

High roa means high profitability.

Highly liquid assets 


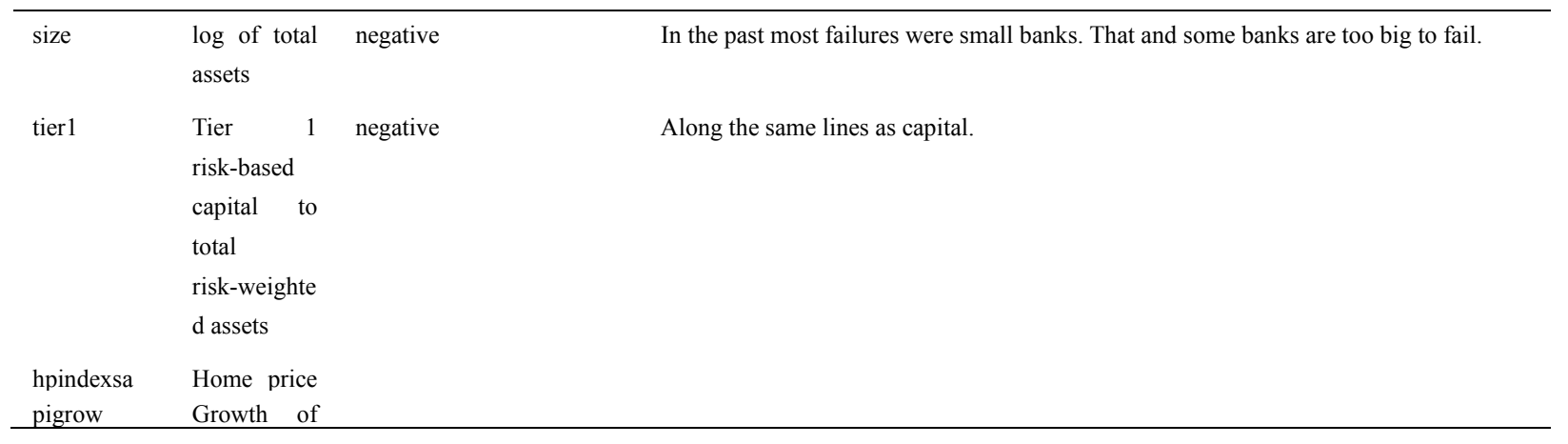

Table 2. Correlation between variables

\begin{tabular}{|c|c|c|c|c|c|c|c|c|c|c|c|c|}
\hline & realloan & $\begin{array}{l}\text { cons_ } \\
\text { devlp }\end{array}$ & comm_real & $\begin{array}{l}\text { mul_ }_{-} \\
\text {family }\end{array}$ & sig_family & ciloan & idloan & deploan & loan growth & capital & size & roa \\
\hline realloan & 1.0000 & & & & & & & & & & & \\
\hline cons_devlp & 0.3423 & 1.0000 & & & & & & & & & & \\
\hline comm_real & 0.2048 & 0.1430 & 1.0000 & & & & & & & & & \\
\hline mul_family & 0.1452 & 0.0522 & 0.1096 & 1.0000 & & & & & & & & \\
\hline sig_family & -0.0557 & -0.4446 & -0.6102 & -0.2059 & 1.0000 & & & & & & & \\
\hline ciloan & -0.1244 & 0.1863 & 0.2546 & 0.0807 & -0.2432 & 1.0000 & & & & & & \\
\hline idloan & -0.3023 & -0.1875 & -0.1665 & -0.0929 & 0.2692 & -0.0446 & 1.0000 & & & & & \\
\hline deploan & -0.0522 & -0.0058 & 0.0135 & 0.0284 & 0.0117 & 0.0249 & 0.0198 & 1.0000 & & & & \\
\hline loangrowth & -0.0129 & 0.0028 & 0.0017 & 0.0094 & 0.0001 & -0.0029 & -0.0053 & 0.0015 & 1.0000 & & & \\
\hline capital & -0.1845 & -0.0016 & -0.0443 & 0.0145 & -0.0229 & -0.0441 & -0.0375 & 0.0462 & 0.0629 & 1.0000 & & \\
\hline size & 0.2896 & 0.2354 & 0.2480 & 0.1944 & -0.0756 & 0.0840 & -0.0855 & 0.0839 & -0.0103 & -0.2127 & 1.0000 & \\
\hline roa & -0.0604 & -0.1047 & -0.0658 & -0.0312 & 0.0464 & -0.0273 & 0.0965 & 0.0026 & -0.0431 & -0.1498 & 0.0655 & 1.0000 \\
\hline lossallow & -0.2173 & -0.0196 & 0.0046 & 0.0116 & -0.0891 & -0.0022 & 0.0977 & 0.0005 & -0.0046 & 0.1466 & -0.0649 & -0.1258 \\
\hline pastdue & 0.1064 & 0.0698 & -0.0287 & 0.0025 & -0.0155 & 0.0410 & 0.0828 & -0.0024 & -0.0091 & -0.0717 & -0.0295 & -0.2562 \\
\hline chargeoff & -0.0311 & 0.0467 & 0.0235 & 0.0379 & -0.0351 & 0.0400 & 0.1119 & 0.0125 & -0.0030 & -0.0253 & 0.0515 & -0.3884 \\
\hline foreclose & 0.1203 & 0.1508 & 0.0503 & 0.0002 & -0.0760 & 0.0045 & -0.0419 & -0.0081 & -0.0040 & -0.0670 & 0.0014 & -0.2247 \\
\hline loan_ast & 0.7152 & 0.2686 & 0.1319 & 0.1022 & -0.1849 & 0.3244 & 0.0249 & 0.0157 & -0.0215 & -0.2312 & 0.1859 & 0.0065 \\
\hline MBS & -0.2363 & -0.0626 & 0.0104 & 0.0180 & 0.0846 & -0.1426 & -0.0734 & -0.0111 & -0.0004 & -0.0555 & 0.1733 & 0.0103 \\
\hline debt_sec & -0.5982 & -0.2883 & -0.1558 & -0.1045 & 0.1938 & -0.3144 & -0.0300 & -0.0369 & -0.0015 & 0.0832 & -0.0958 & 0.0898 \\
\hline loansale & 0.0385 & 0.0290 & 0.0096 & 0.0070 & -0.0053 & 0.0073 & -0.0157 & -0.0015 & 0.0016 & -0.0064 & 0.0234 & -0.0064 \\
\hline insureddep & -0.0658 & -0.3012 & -0.3195 & -0.1238 & 0.2735 & -0.2398 & 0.1627 & -0.0800 & -0.0129 & -0.0366 & -0.3820 & 0.0208 \\
\hline pi_grow & -0.0470 & 0.0411 & 0.0031 & -0.0168 & -0.0351 & 0.0133 & 0.0224 & -0.0005 & 0.0042 & 0.0066 & -0.0198 & 0.0769 \\
\hline hpindex_sa & 0.1872 & 0.2258 & 0.0884 & 0.0656 & -0.1968 & 0.0326 & -0.1997 & -0.0030 & 0.0061 & 0.0598 & 0.0796 & -0.0329 \\
\hline
\end{tabular}


Table 2. Correlation between variables (Continued)

\begin{tabular}{|c|c|c|c|c|c|c|c|c|c|c|c|}
\hline & lossallow & pastdue & chargeoff & foreclose & loan_ast & MBS & debt_sec & loansale & insured dep & pi_grow & hpindex_sa \\
\hline lossallow & 1.0000 & & & & & & & & & & \\
\hline pastdue & 0.2693 & 1.0000 & & & & & & & & & \\
\hline chargeoff & 0.2302 & 0.3187 & 1.0000 & & & & & & & & \\
\hline foreclose & 0.1286 & 0.4013 & 0.2264 & 1.0000 & & & & & & & \\
\hline loan_ast & -0.1708 & 0.1890 & 0.0230 & 0.0893 & 1.0000 & & & & & & \\
\hline MBS & 0.0111 & -0.1075 & -0.0053 & -0.0458 & -0.4255 & 1.0000 & & & & & \\
\hline debt_sec & 0.1168 & -0.1820 & -0.0445 & -0.1225 & -0.8454 & 0.5232 & 1.0000 & & & & \\
\hline loansale & -0.0087 & -0.0012 & 0.0026 & 0.0005 & 0.0296 & -0.0049 & -0.0282 & 1.0000 & & & \\
\hline insureddep & -0.0013 & 0.1178 & 0.0024 & 0.0444 & -0.0400 & -0.0495 & 0.0992 & -0.0136 & 1.0000 & & \\
\hline pi_grow & -0.0186 & -0.1135 & -0.0581 & -0.0967 & -0.0295 & -0.0190 & 0.0222 & 0.0031 & -0.0454 & 1.0000 & \\
\hline hpindex_sa & -0.0412 & -0.0042 & -0.0142 & 0.0151 & 0.1450 & -0.0525 & -0.1372 & 0.0063 & -0.1907 & 0.0879 & 1.0000 \\
\hline
\end{tabular}

Table 3. Collinearity diagnostics for model 1

\begin{tabular}{lcccc}
\hline Variable & VIF & SQRT VIF & Tolerance & R-Squared \\
\hline realloan & 1.25 & 1.12 & 0.8001 & 0.1999 \\
idloan & 1.12 & 1.06 & 0.8897 & 0.1103 \\
deploan & 1.02 & 1.01 & 0.9780 & 0.0220 \\
loangrowth & 1.00 & 1.00 & 0.9951 & 0.0049 \\
capital & 1.10 & 1.05 & 0.9105 & 0.0895 \\
size & 1.13 & 1.06 & 0.8880 & 0.1120 \\
\hline roa & 1.03 & 1.02 & 0.9706 & 0.0294 \\
Mean VIF & 1.09 & & & \\
\hline
\end{tabular}

Table 4. Comparison of a priori hypotheses with results of univariate analysis (Tables $5 \& 6$ ) and probit analysis (tables 7, 8, \& 9)

\begin{tabular}{|c|c|c|c|c|c|c|c|}
\hline Variable & Description & Expected Sign & Table 5 & Table 6 & Table 7 & Table 8 & Table 9 \\
\hline ciloan & commercial and industrial loans to total assets & uncorrelated & uncorrelated & uncorrelated & & negative & negative \\
\hline mul_family & multifamily residential real estate loans to real estate loans & uncorrelated & positive & positive & & positive & positive \\
\hline sig_family & 1-4 family residential loans to real estate loans & uncorrelated & negative & negative & & uncorrelated & uncorrelated \\
\hline trade_ast & trading account assets to total assets & uncorrelated & uncorrelated & negative & & & \\
\hline brokdep & brokered deposits to total deposits & positive & positive & positive & & & \\
\hline chargeoff & net charge offs to average loans & positive & positive & positive & & uncorrelated & uncorrelated \\
\hline comm_real & commercial real estate loans to real estate loans & positive & uncorrelated & uncorrelated & & positive & positive \\
\hline cons_devlp & construction and land development loans to real estate loans & positive & positive & positive & & positive & positive \\
\hline foreclosure & real estate acquired through foreclosure to total assets & positive & positive & positive & & uncorrelated & uncorrelated \\
\hline loanast & Total loans to total assets & positive & positive & positive & $\mathrm{N} / \mathrm{U}$ & $\mathrm{N} / \mathrm{U}$ & uncorrelated \\
\hline loansale & net gains on sales of loans to total non-interest income & positive & positive & uncorrelated & & uncorrelated & uncorrelated \\
\hline lossallow & loan loss allowance to total loans & positive & positive & positive & $\mathrm{P} / \mathrm{U}$ & positive & positive \\
\hline pastdue & non-performing loans to total assets & positive & positive & positive & positive & positive & positive \\
\hline capital & equity capital to total assets & negative & negative & negative & $\mathrm{N} / \mathrm{U}$ & negative & $\mathrm{N} / \mathrm{U}$ \\
\hline
\end{tabular}




\begin{tabular}{|c|c|c|c|c|c|c|c|}
\hline cash & cash and due from depository institutions to total assets & negative & negative & negative & & & \\
\hline debt_sec & total short-term debt security to total assets & negative & negative & negative & $\mathrm{N} / \mathrm{U}$ & negative & negative \\
\hline deploan & loans to depository institutions to total assets & negative & negative & negative & & uncorrelated & uncorrelated \\
\hline idloan & loans to individuals to total assets & negative & negative & negative & & negative & negative \\
\hline insureddep & Insured deposits to total deposits & negative & negative & $\mathrm{P} / \mathrm{U}$ & & negative & negative \\
\hline interbank & interbank deposits to total deposits & negative & positive & positive & & & \\
\hline loangrowth & growth of total loans and leases & negative & negative & negative & & uncorrelated & uncorrelated \\
\hline MBS & mortgage-backed securities to total assets & negative & negative & negative & $\mathrm{P} / \mathrm{U}$ & uncorrelated & uncorrelated \\
\hline non_income & non-interest income to total income & negative & negative & negative & & & \\
\hline off-bal & off-balance sheet derivatives to total assets & negative & uncorrelated & uncorrelated & & & \\
\hline realloan & real estate loans to total assets & negative & positive & positive & positive & positive & positive \\
\hline roa & return on assets & negative & negative & negative & negative & negative & negative \\
\hline sec_asset & securities to total assets & negative & negative & negative & & & \\
\hline size & $\log$ of total assets & negative & positive & positive & positive & positive & positive \\
\hline tier1 & Tier 1 risk-based capital to total risk-weighted assets & negative & negative & negative & & & \\
\hline hpindexsa & Home price index seasonal adjusted & & & & $\mathrm{P} / \mathrm{U}$ & positive & positive \\
\hline pigrow & Growth of personal income & & & & mixed & negative & uncorrelated \\
\hline
\end{tabular}

We begin by comparing the sample of failed and surviving banks using a univariate t-test for the difference of mean values for 29 variables at two times, the $4^{\text {th }}$ quarter of 2007 and the $4^{\text {th }}$ quarter of 2008 . According to the National Bureau of Economic Research the recession began in December 2007 and the financial meltdown that followed was in high gear by the end of 2008.

Next, we employ a probit regression with a dummy dependent variable (fail) coded 1 for failed banks and 0 for surviving banks. We test five models designed to determine the cause of bank failures during the 2008 to 2010 period. These five models examine risk associated with lending, detailed lending, liquidity and lending, lending and market trading, lending and market trading, as well as market conditions, respectively. The probit regressions are run with rolling windows, consisting of six combinations of time between the independent variables and failure dummy variable, and fixed windows at the two time periods stated above.

Model 1:

$$
\text { Fail }=\beta_{0}+\beta_{1} \text { capital }+\beta_{2} \text { deploan }+\beta_{3} \text { idloan }+\beta_{4} \text { loangrowth }+\beta_{5} \text { reallaon }+\beta_{6} \text { roa }+\beta_{7} \text { size }
$$

Model 2:

$$
\begin{gathered}
\text { Fail }=\beta_{0}+\beta_{1} \text { capital }+\beta_{2} \text { ciloan }+\beta_{3} \text { mulfamily }+\beta_{4} \text { sigfamily }+\beta_{5} \text { commreal }+\beta_{6} \text { consdevlp } \\
+\beta_{7} \text { roa }+\beta_{8} \text { size }
\end{gathered}
$$

Model 3:

$$
\begin{gathered}
\text { Fail }=\beta_{0}+\beta_{1} \text { capital }+\beta_{2} \text { chargeoff }+\beta_{3} \text { foreclosure }+\beta_{4} \text { lossallow }+\beta_{5} \text { pastdue }+\beta_{6} \text { loangrowth } \\
+\beta_{7} \text { realloan }+\beta_{8} \text { roa }+\beta_{9} \text { size }
\end{gathered}
$$

Model 4:

$$
\begin{gathered}
\text { Fail }=\beta_{0}+\beta_{1} \text { capital }+\beta_{2} \text { loanast }+\beta_{3} \text { loansale }+\beta_{4} \text { lossallow }+\beta_{5} \text { pastdue }+\beta_{6} \text { debtsec } \\
+\beta_{7} \text { insureddep }+\beta_{8} M B S+\beta_{9} \text { realloan }+\beta_{10} \text { roa }+\beta_{11} \text { size }
\end{gathered}
$$

Model 5:

$$
\begin{gathered}
\text { Fail }=\beta_{0}+\beta_{1} \text { capital }+\beta_{2} \text { loanast }+\beta_{3} \text { lossallow }+\beta_{4} \text { pastdue }+\beta_{5} \text { debtsec }+\beta_{6} M B S+\beta_{7} \text { realloan } \\
+\beta_{8} \text { roa }+\beta_{9} \text { size }+\beta_{10} \text { hpindexsa }+\beta_{11} \text { pigrow }
\end{gathered}
$$

\section{Results}

Table 4 compares the results of the univariate and probit analysis to our a priori hypothesis with Tables $5,6,7,8$, and 9 providing supporting details. Tables 5 and 6 provide descriptive statistics and the results of the univariate t-test on mean differences between failed and surviving banks. Table 7 provides the results of the rolling window 
probit regressions using model 5 over six combinations of time, while Tables 8 and 9 report the fixed window results of the probit regressions for all five models using $4^{\text {th }}$ quarter 2007 data to predict failure between 2008 and 2010; and $4^{\text {th }}$ quarter 2006 data to predict failure between 2008 and 2010 respectively.

We hypothesize that banks face risks from four sources: lending, liquidity, market trading, and market conditions.

Table 5. Descriptive statistics and univariate t-test for mean differences (2007Q4)

\begin{tabular}{|c|c|c|c|c|c|c|c|c|c|}
\hline variable & $\begin{array}{l}\text { failed } \\
\text { banks }\end{array}$ & $\begin{array}{l}\text { Surviving } \\
\text { banks }\end{array}$ & $\begin{array}{l}\text { Difference } \\
\text { (t-stat) }\end{array}$ & & variable & $\begin{array}{l}\text { Failed } \\
\text { banks }\end{array}$ & $\begin{array}{l}\text { Surviving } \\
\text { banks }\end{array}$ & $\begin{array}{l}\text { Difference } \\
\text { (t-stat) }\end{array}$ & \\
\hline \multirow[t]{2}{*}{ realloan } & 64.13 & 47.33 & 16.80 & & size & 12.88 & 11.91 & 0.96 & \\
\hline & (14.98) & (19.84) & (14.07) & $* * *$ & & (1.61) & (1.38) & (7.58) & $* * *$ \\
\hline \multirow[t]{2}{*}{ cons_devlp } & 39.45 & 15.08 & 24.37 & & roa & -1.84 & 0.51 & -2.35 & \\
\hline & (23.11) & (15.28) & (13.40) & $* * *$ & & (5.39) & (5.97) & $(-5.49)$ & $* * *$ \\
\hline \multirow[t]{2}{*}{ comm_real } & 28.53 & 30.58 & -2.05 & & sec_asset & 12.78 & 20.07 & -7.29 & \\
\hline & (16.47) & (18.27) & $(-1.57)$ & & & $(10.52)$ & (15.13) & $(-8.66)$ & $* * *$ \\
\hline \multirow[t]{2}{*}{ mul_family } & 4.97 & 2.83 & 2.14 & & trade_ast & 0.09 & 0.1 & -0.013 & \\
\hline & (7.97) & (5.93) & $(3.41)$ & $* * *$ & & $(0.39)$ & $(1.43)$ & $(-0.39)$ & \\
\hline \multirow[t]{2}{*}{ sig_family } & 24.34 & 40.81 & -16.47 & & MBS & 5.14 & 6.33 & -1.18 & \\
\hline & (22.94) & (23.76) & $(-9.07)$ & $* * *$ & & $(6.15)$ & $(9.27)$ & $(-2.40)$ & $* *$ \\
\hline \multirow[t]{2}{*}{ Ciloan } & 8.84 & 9.35 & -0.51 & & off_bal & 1.97 & 3.46 & -1.49 & \\
\hline & (7.53) & $(7.65)$ & $(-0.86)$ & & & (7.93) & (94.45) & $(-1.15)$ & \\
\hline \multirow[t]{2}{*}{ Idloan } & 1.64 & 4.67 & -3.03 & & debt_sec & 12.2 & 19.71 & -7.51 & \\
\hline & $(2.07)$ & (6.74) & $(-16.96)$ & $* * *$ & & (10.36) & (14.92) & $(-9.07)$ & $* * *$ \\
\hline \multirow[t]{2}{*}{ deploan } & 0.012 & 0.071 & -0.06 & & loansale & 1.75 & 0.16 & 1.59 & \\
\hline & $(0.11)$ & (1.19) & $(-3.54)$ & $* * *$ & & $(5.11)$ & $(61.10)$ & $(2.00)$ & $* *$ \\
\hline \multirow[t]{2}{*}{ loangrowth } & 3.75 & 9.33 & -5.58 & & brokdep & 16.14 & 4.06 & 12.08 & \\
\hline & (15.94) & (165.27) & $(-2.49)$ & $* *$ & & (19.86) & $(10.15)$ & (7.75) & $* * *$ \\
\hline \multirow[t]{2}{*}{ lossallow } & 1.85 & 1.29 & 0.56 & & interbank & 5.51 & 1.54 & 3.97 & \\
\hline & $(1.33)$ & (1.48) & $(5.28)$ & $* * *$ & & (13.02) & $(7.74)$ & (3.88) & $* * *$ \\
\hline \multirow[t]{2}{*}{ chargeoff } & 0.36 & 0.11 & 0.25 & & non_income & 4.23 & 10.05 & -5.82 & \\
\hline & $(0.75)$ & $(0.40)$ & $(4.38)$ & $* * *$ & & (22.03) & $(17.51)$ & $(-3.35)$ & $* * *$ \\
\hline \multirow[t]{2}{*}{ pastdue } & 5.72 & 1.72 & 4.00 & & cash & 2.37 & 4.65 & -2.27 & \\
\hline & $(5.57)$ & $(1.80)$ & $(9.15)$ & $* * *$ & & $(2.06)$ & $(5.55)$ & $(-13.18)$ & $* * *$ \\
\hline \multirow[t]{2}{*}{ foreclose } & 0.75 & 0.18 & 0.56 & & loan_ast & 76.24 & 66.20 & 10.04 & \\
\hline & (1.19) & $(0.51)$ & $(6.04)$ & $* * *$ & & (12.37) & (17.57) & (10.16) & $* * *$ \\
\hline \multirow[t]{2}{*}{ Capital } & 9.75 & 12.73 & -2.99 & & insureddep & 71.91 & 75.17 & -3.26 & \\
\hline & $(4.35)$ & $(9.68)$ & $(-8.35)$ & $* * *$ & & (16.19) & (16.06) & $(-2.55)$ & $* *$ \\
\hline \multirow[t]{2}{*}{ tier1 } & 10.85 & 22.1 & -11.25 & & & & & & \\
\hline & $(4.21)$ & (116.16) & $(-8.41)$ & $* * *$ & & & & & \\
\hline
\end{tabular}

Note: We obtained the results by using the cross-sectional data of 2007Q4. Failure dummy variable defined as banks that failed in 2008-2009. We reported the mean of explanatory variables for surviving and failed banks in the first two columns. The standard deviations are in the parenthesis. We also present the difference in mean and the t-statistic in the third column which tests the mean difference of both sample banks. *, ** and $* * *$ significant at the $10 \%, 5 \%$ and $1 \%$ level, variables are described in Table 1 . 
For lending, we expected financial ratios with high levels of commercial real estate loans to real estate loans and construction and land development loans to real estate loans to be positively correlated with bank failure and probit analysis bears this out, though univariate analysis disclose no statistically significant relationship between the risk of bank failure and commercial real estate loans to real estate loans. We expected loans to depository institutions to total assets, loans to individuals to total assets, growth of total loans and leases, and real estate loans to total assets to be negatively correlated with bank failure. This is true based on the univariate analysis for all variables except real estate loans to total assets which has a positive association.

Probit analysis also shows a positive association for real estate loans to total assets, but reveals loans to depository institutions to total assets and growth of total loans and leases to be uncorrelated. We expected commercial and industrial loans to total assets, multifamily residential real estate loans to real estate loans, and 1-4 family residential loans to real estate loans to be uncorrelated with the risk of bank failure. Both univariate and probit analysis indicate that multifamily residential real estate loans to real estate loans are positively associated with the risk of bank failure while univariate analysis shows commercial and industrial loans to total assets to be uncorrelated as expected, but 1-4 family residential loans to real estate loans to have a negative association. Probit analysis indicates the opposite, i.e. 1-4 family residential loans to real estate loans has no association with bank failure while commercial and industrial loans to total assets has a negative association.

For lending, we find that multifamily residential real estate loans to real estate loans, construction and land development loans to real estate loans, and real estate loans to total assets increase the odds of failure and loans to individuals to total assets decrease the odds of failure. Probit analysis reveals that the apparent effect of 1-4 family residential loans to real estate loans, loans to depository institutions to total assets, and growth of total loans and leases disappears after controlling for other variables.

For liquidity, we expected net charge offs to average loans, real estate acquired through foreclosure to total assets, loan loss allowance to total loans, and non-performing loans to total assets to be positively correlated with the risk of bank failure. This is true according to univariate analysis, but probit regressions uncover no effect after controlling for other variables except for loan loss allowance to total loans and non-performing loans to total assets.

For market trading, we expected total loans to total assets and net gains on sales of loans to total non-interest income to have a positive association with the risk of bank failure, which is what univariate analysis shows for both in 2007 but only for the first in 2006. Probit analysis establishes that these effects largely disappear after controlling for other variables. We expected a negative relationship between the risk of bank failure and total short-term debt security to total assets, insured deposits to total deposits, and mortgage-backed securities to total assets. This relationship holds under univariate analysis, but probit analysis proves that after controlling for other variables only the first remains significant.

We expected capital, cash, interbank deposits to total deposits, return on assets, and size to all be negatively associated with the risk of bank failure, which is what we find for capital, cash, and return on assets (though some of the probit regressions show capital being insignificant after controlling for other variables.) We are surprised by the finding that size and interbank deposits to total deposits are positively associated with the risk of bank failure (even after controlling for other variables in the case of size).

Table 6. Descriptive statistics and univariate t-test for mean differences (2008Q4)

\begin{tabular}{|c|c|c|c|c|c|c|c|c|c|}
\hline variable & $\begin{array}{l}\text { failed } \\
\text { banks }\end{array}$ & $\begin{array}{l}\text { Surviving } \\
\text { banks }\end{array}$ & $\begin{array}{l}\text { Difference } \\
\text { (t-stat) }\end{array}$ & & variable & $\begin{array}{l}\text { Failed } \\
\text { banks }\end{array}$ & $\begin{array}{l}\text { Surviving } \\
\text { banks }\end{array}$ & $\begin{array}{l}\text { Difference } \\
\text { (t-stat) }\end{array}$ & \\
\hline realloan & 63.57 & 48.45 & 15.13 & & size & 12.65 & 11.98 & 0.67 & $* * *$ \\
\hline \multirow{3}{*}{ cons_devlp } & (13.78) & (19.59) & 18.06 & $* * *$ & & $(1.36)$ & $(1.37)$ & $(8.30)$ & \\
\hline & 31.95 & 13.04 & 18.91 & & roa & -7.65 & -0.22 & -7.43 & $* * *$ \\
\hline & (17.82) & (12.59) & 17.91 & $* * *$ & & $(8.81)$ & (5.13) & $(-14.31)$ & \\
\hline \multirow[t]{2}{*}{ comm_real } & 33.13 & 31.82 & 1.31 & & sec_asset & 10.77 & 19.18 & -9.03 & $* * *$ \\
\hline & (16.04) & $(18.50)$ & 1.36 & & & $(8.64)$ & (15.13) & $(-16.89)$ & \\
\hline \multirow[t]{2}{*}{ mul_family } & 5.27 & 3.03 & 2.23 & & trade_ast & 0.003 & 0.08 & -0.08 & $* * *$ \\
\hline & (7.76) & (5.93) & 4.85 & $* * *$ & & $(0.02)$ & $(1.35)$ & $(-5.14)$ & \\
\hline sig_family & 27.04 & 41.18 & -14.14 & & MBS & 5.9 & 7.85 & -1.95 & $* * *$ \\
\hline
\end{tabular}




\begin{tabular}{|c|c|c|c|c|c|c|c|c|c|}
\hline & (20.62) & (23.07) & -11.41 & $* * *$ & & $(6.65)$ & $(10.42)$ & $(-4.80)$ & \\
\hline \multirow[t]{2}{*}{ Ciloan } & 9.08 & 9.2 & -0.13 & & off_bal & 1.06 & 6.74 & -5.68 & \\
\hline & $(7.42)$ & (7.58) & -0.29 & & & $(4.36)$ & (309.91) & $(-1.54)$ & \\
\hline \multirow[t]{2}{*}{ Idloan } & 1.66 & 4.93 & -2.73 & & debt_sec & 10.6 & 19.55 & -8.94 & \\
\hline & $(2.22)$ & $(6.60)$ & -18.18 & $* * *$ & & $(8.47)$ & (14.96) & $(-17.06)$ & $* * *$ \\
\hline \multirow[t]{2}{*}{ deploan } & 0.03 & 0.06 & -0.03 & & loansale & 1.45 & 0.71 & 0.74 & \\
\hline & $(0.30)$ & $(1.30)$ & -1.19 & & & (14.27) & (11.59) & $(0.87)$ & \\
\hline \multirow[t]{2}{*}{ loangrowth } & -1.7 & 3.46 & -5.16 & & brokdep & 19.19 & 5.47 & 13.72 & \\
\hline & $(7.30)$ & (20.33) & -10.61 & $* * *$ & & (18.59) & (11.80) & (12.49) & $* * *$ \\
\hline \multirow[t]{2}{*}{ lossallow } & 2.91 & 1.4 & 1.51 & & interbank & 6.36 & 1.84 & 4.52 & \\
\hline & $(2.09)$ & $(0.86)$ & 12.32 & $* * *$ & & (12.96) & $(8.02)$ & $(5.91)$ & $* * *$ \\
\hline \multirow[t]{2}{*}{ chargeoff } & 1.15 & 0.23 & 0.92 & & non_income & -6.98 & 10.41 & -17.38 & \\
\hline & $(1.32)$ & $(0.57)$ & 11.86 & $* * *$ & & (137.39) & (20.34) & $(-2.16)$ & $* *$ \\
\hline \multirow[t]{2}{*}{ pastdue } & 9.82 & 2.37 & 7.45 & & cash & 4.81 & 5.86 & -1.05 & \\
\hline & $(6.40)$ & $(2.41)$ & 19.8 & $* * *$ & & $(5.31)$ & $(7.26)$ & $(-3.27)$ & $* * *$ \\
\hline \multirow[t]{2}{*}{ foreclose } & 2.03 & 0.37 & 1.66 & & loan_ast & 76.00 & 66.94 & 9.06 & \\
\hline & $(2.75)$ & $(0.76)$ & 10.27 & $* * *$ & & (11.07) & (17.08) & (13.39) & $* * *$ \\
\hline \multirow[t]{2}{*}{ Capital } & 6.83 & 11.85 & -5.02 & & insureddep & 77.30 & 76.22 & 1.08 & \\
\hline & (3.09) & (7.87) & -24.91 & $* * *$ & & (13.86) & (14.86) & $(1.31)$ & \\
\hline \multirow[t]{2}{*}{ tier1 } & 8.32 & 19.62 & -11.3 & & & & & & \\
\hline & $(4.08)$ & $(77.80)$ & -12.44 & $* * *$ & & & & & \\
\hline
\end{tabular}

Note: We obtained the results by using the cross-sectional data of 2008Q4. Failure dummy variable defined as banks that failed in 2009-2010. We reported the mean of explanatory variables for surviving and failed banks in the first two columns. The standard deviations are in the parenthesis. We also present the difference in mean and the t-statistic in the third column which tests the mean difference of both sample banks. *, ** and *** significant at the $10 \%, 5 \%$ and $1 \%$ level, variables are described in Table 1 .

Table 7 has the results for the rolling window probit regressions using model 5. The first 3 columns analyze failures which occurred in 2008-2009 using data from 2005, 2006, and 2007 while the next 3 columns analyze failures which occurred in 2009-2010 using data from 2006, 2007, and 2008. The model for predicting failure in 2009-2010 using data from 2008 was run without capital as the model would not converge in Stata. Given the results for the other models, i.e. capital is either significant at the $1 \%$ level or not significant at all, we believe that the iteration process in Stata is reaching a plateau or ridge where the log-likelihood does not change though capital continues to change significantly. As expected, the closer the time period of the independent variables to the date of failure for the dependent variables, the better the models' fit based on all of the diagnostics run: Pseudo $\mathrm{R}^{2}$, Efron's $\mathrm{R}^{2}, \mathrm{LR} \mathrm{x}^{2}$, AIC, and BIC; and the better able to correctly predict which banks would fail. The models analyzing failure in 2009-2010 performed better than the corresponding models analyzing failure in 2008-2009 due to the worsening financial conditions and greater number of bank failures in the later time period.

Table 7. Probit regression results: comparison of different time periods (rolling windows)

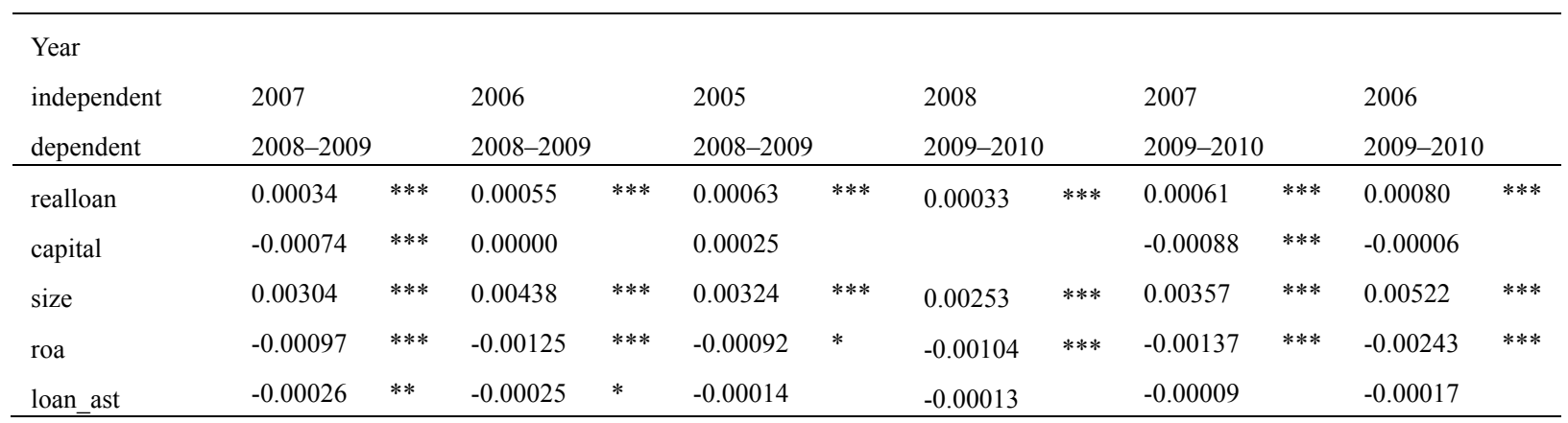




\begin{tabular}{|c|c|c|c|c|c|c|c|c|c|c|c|c|}
\hline lossallow & 0.00046 & $*$ & 0.00067 & & 0.00098 & & 0.00259 & $* * *$ & 0.00120 & $* *$ & 0.00184 & $*$ \\
\hline pastdue & 0.00278 & $* * *$ & 0.00182 & $* * *$ & 0.00075 & & 0.00316 & $* * *$ & 0.00384 & $* * *$ & 0.00279 & $* * *$ \\
\hline MBS & 0.00001 & & -0.00018 & & -0.00002 & & 0.00047 & $* * *$ & 0.00026 & & 0.00000 & \\
\hline debt_sec & -0.00016 & & -0.00017 & & 0.00001 & & -0.00043 & $* * *$ & -0.00046 & $* *$ & -0.00046 & $* *$ \\
\hline pi_grow & -0.04038 & & -0.02015 & & 0.45611 & $* *$ & -0.45232 & $* * *$ & -0.63004 & $* * *$ & -0.16257 & \\
\hline hpindex_sa & 0.00005 & $* *$ & 0.00009 & $* * *$ & 0.00010 & $* * *$ & -0.00002 & & 0.00020 & $* * *$ & 0.00027 & $* * *$ \\
\hline \multicolumn{13}{|l|}{ Model Stat. } \\
\hline Obs & 8121 & & 8113 & & 8298 & & 8111 & & 8121 & & 8113 & \\
\hline Loglikelihood & -590.61 & & -661.14 & & -695.15 & & -741.75 & & -997.26 & & -1033.68 & \\
\hline Pseudo $R^{2}$ & 0.2603 & & 0.1467 & & 0.1115 & & 0.4085 & & 0.2050 & & 0.1417 & \\
\hline Efron's $R^{2}$ & 0.136 & & 0.039 & & 0.030 & & 0.301 & & 0.104 & & 0.051 & \\
\hline $\operatorname{LR} x^{2}$ & 415.64 & & 227.39 & & 174.41 & & 1024.63 & & 514.33 & & 341.36 & \\
\hline p-value & 0.000 & & 0.000 & & 0.000 & & 0.000 & & 0.000 & & 0.000 & \\
\hline $\mathrm{AIC}$ & 1205.22 & & 1346.28 & & 1414.29 & & 1505.49 & & 2018.52 & & 2091.36 & \\
\hline BIC & 1289.25 & & 1430.292 & & 1498.579 & & 1582.504 & & 2102.549 & & 2175.375 & \\
\hline \multicolumn{13}{|c|}{ Classification results: Percentage correct } \\
\hline Failure & $7.98 \%$ & & $0.00 \%$ & & $0.00 \%$ & & $23.71 \%$ & & $2.75 \%$ & & $0.00 \%$ & \\
\hline Non-Failure & $99.89 \%$ & & $99.97 \%$ & & $100.00 \%$ & & $99.59 \%$ & & $99.82 \%$ & & $99.96 \%$ & \\
\hline $\begin{array}{l}\text { Correctly } \\
\text { classified }\end{array}$ & $98.04 \%$ & & $98.04 \%$ & & $98.10 \%$ & & $96.87 \%$ & & $96.34 \%$ & & $96.56 \%$ & \\
\hline
\end{tabular}

Notes: We report the marginal effect of a change in the relevant independent variables in a probit regression model and the classification of models.

*,** and *** indicate statistical significance at $10 \%, 5 \%, 1 \%$ level, respectively. All variables are described in Table 1.

The model for predicting failure in 2009-2010 using data from 2008 was run without capital as the model would not converge in Stata. Given the results for the other models, ie capital is either significant at the $1 \%$ level or not significant at all, we believe that the iteration process in Stata is reaching a plateau or ridge where the log-likelihood does not change though capital continues to change significantly.

Tables 8 and 9 display the fixed window probit regression results for each of the five models. Table 8 is fixed at the $4^{\text {th }}$ quarter of 2007 for the independent variables with the dependent variable of bank failures for the 2008-2010 periods whereas Table 9 is fixed at the $4^{\text {th }}$ quarter of 2006. All five models are highly significant with $\mathrm{p}$-values less than $1 \%$. In each time period, model 2 (mainly detailed lending factors) has the highest Pseudo $\mathrm{R}^{2}$ and Efron's $\mathrm{R}^{2}$ and model 3 (liquidity and lending) has the lowest (best) AIC and BIC. Using 2006 data (Table 9), model 2 is best able to predict which banks will fail, but only $1.33 \%$ are correctly classified (overall, model 1 (lending) was able to classify $96.45 \%$ of all banks correctly), while using 2007 data model 5 (lending, market trading, and overall market conditions) was best at correctly classifying failed banks at $9.84 \%$, and best overall at $96.29 \%$. Model 4 (lending and market trading) was least able to detect bank failures.

For robustness testing purposes, we ran the regressions using logit. The estimates of the coefficients in the models remain qualitatively unaffected and robust.

Table 8. Probit regression results: 2007Q4 (fixed window)






\begin{tabular}{|c|c|c|c|c|c|c|c|c|c|c|}
\hline \multirow[t]{2}{*}{ mul_family } & & & 0.0010905 & & & & & & & \\
\hline & & & $(6.06)$ & $* * *$ & & & & & & \\
\hline \multirow[t]{2}{*}{ sig_family } & & & 0.000198 & & & & & & & \\
\hline & & & $(1.42)$ & & & & & & & \\
\hline \multirow[t]{2}{*}{ ciloan } & & & -0.0004606 & & & & & & & \\
\hline & & & $(-2.87)$ & $* * *$ & & & & & & \\
\hline \multirow[t]{2}{*}{ idloan } & -0.0033285 & & & & & & & & & \\
\hline & $(-7.32)$ & $* * *$ & & & & & & & & \\
\hline \multirow[t]{2}{*}{ deploan } & -0.0027762 & & & & & & & & & \\
\hline & $(-0.69)$ & & & & & & & & & \\
\hline \multirow[t]{2}{*}{ loangrowth } & -0.0000043 & & & & -0.00000196 & & & & & \\
\hline & $(-0.10)$ & & & & $(-0.19)$ & & & & & \\
\hline \multirow{2}{*}{ capital } & -0.0008512 & & -0.002083 & & -0.0007457 & & -0.0010358 & & -0.0011326 & \\
\hline & $(-3.11)$ & $* * *$ & $(-7.91)$ & $* * *$ & $(-2.36)$ & $* *$ & $(-3.70)$ & $* * *$ & $(-4.16)$ & $* * *$ \\
\hline \multirow[t]{2}{*}{ size } & 0.0030773 & & 0.001799 & & 0.0057521 & & 0.0035459 & & 0.0043887 & \\
\hline & (3.24) & $* * *$ & (2.09) & $* *$ & $(6.07)$ & $* * *$ & $(3.92)$ & $* * *$ & $(5.11)$ & $* * *$ \\
\hline \multirow[t]{2}{*}{ roa } & -0.0027406 & & -0.0029355 & & -0.0026512 & & -0.0022033 & & -0.0020595 & \\
\hline & $(-6.46)$ & $* * *$ & $(-7.94)$ & $* * *$ & $(-6.00)$ & $* * *$ & $(-5.85)$ & $* * *$ & $(-5.74)$ & $* * *$ \\
\hline \multirow[t]{2}{*}{ lossallow } & & & & & 0.0016254 & & 0.0016654 & & 0.0013263 & \\
\hline & & & & & $(3.20)$ & $* * *$ & $(3.52)$ & $* * *$ & $(2.91)$ & $* * *$ \\
\hline \multirow[t]{2}{*}{ pastdue } & & & & & 0.0055075 & & 0.0053497 & & 0.0049806 & \\
\hline & & & & & $(9.17)$ & $* * *$ & $(9.08)$ & $* * *$ & $(8.79)$ & $* * *$ \\
\hline \multirow[t]{2}{*}{ chargeoff } & & & & & 0.0005629 & & & & & \\
\hline & & & & & $(0.18)$ & & & & & \\
\hline \multirow[t]{2}{*}{ foreclose } & & & & & 0.0024468 & & & & & \\
\hline & & & & & $(1.37)$ & & & & & \\
\hline \multirow[t]{2}{*}{ loan_ast } & & & & & & & -0.0003231 & & -0.0002103 & \\
\hline & & & & & & & $(-1.66)$ & $*$ & $(-1.10)$ & \\
\hline \multirow[t]{2}{*}{ MBS } & & & & & & & 0.000349 & & 0.000262 & \\
\hline & & & & & & & (1.39) & & $(1.08)$ & \\
\hline \multirow[t]{2}{*}{ debt_sec } & & & & & & & -0.0006404 & & -0.0005997 & \\
\hline & & & & & & & $(-3.00)$ & $* * *$ & $(-2.85)$ & $* * *$ \\
\hline \multirow[t]{2}{*}{ loansale } & & & & & & & 0.000242 & & & \\
\hline & & & & & & & $(1.42)$ & & & \\
\hline insureddep & & & & & & & -0.0003662 & & & \\
\hline & & & & & & & $(-4.55)$ & $* * *$ & & \\
\hline pi_grow & & & & & & & & & -0.4476449 & \\
\hline & & & & & & & & & $(-2.50)$ & $* *$ \\
\hline hpindex_sa & & & & & & & & & 0.0001802 & \\
\hline & & & & & & & & & $(5.46)$ & $* * *$ \\
\hline Model Stat. & & & & & & & & & & \\
\hline observations & 7318 & & 8073 & & 8068 & & 8066 & & 8121 & \\
\hline LR chi2 & 420.73 & & 679.61 & & 608.26 & & 642.63 & & 657.22 & \\
\hline Prob $>$ chi 2 & 0.000 & & 0.000 & & 0.000 & & 0.000 & & 0.000 & \\
\hline Log likelihood & -952.02 & & -987.53 & & -1026.21 & & -1008.95 & & -1003.83 & \\
\hline Pseudo R2 & 0.181 & & 0.256 & & 0.2286 & & 0.2415 & & 0.2466 & \\
\hline Efron's R2 & 0.092 & & 0.165 & & 0.148 & & 0.157 & & 0.161 & \\
\hline AIC & 1920.04 & & 1993.06 & & 2072.43 & & 2041.90 & & 2031.67 & \\
\hline BIC & 1975.22 & & 2056.03 & & 2142.38 & & 2125.84 & & 2115.70 & \\
\hline Failure & $1.10 \%$ & & $6.37 \%$ & & $8.89 \%$ & & $8.57 \%$ & & $9.84 \%$ & \\
\hline Non-Failure & $99.96 \%$ & & $99.83 \%$ & & $99.79 \%$ & & $99.82 \%$ & & $99.78 \%$ & \\
\hline Correctly & & & & & & & & & & \\
\hline Classified & $96.28 \%$ & & $96.20 \%$ & & $96.24 \%$ & & $96.26 \%$ & & $96.29 \%$ & \\
\hline
\end{tabular}

Notes: We report the marginal effect of a change in the relevant independent variables in a probit regression model and the classification of models. 
Z-statistics are in the parentheses. ${ }^{*}, *$ and $* * *$ indicate statistical significance at $10 \%, 5 \%, 1 \%$ level, respectively. All variables are described in Table 1.

Table 9. Probit regression results: 2006Q4






\begin{tabular}{llllll}
\hline $\begin{array}{l}\text { Model Stat. } \\
\text { observations }\end{array}$ & 7316 & 8059 & 8068 & 8073 & 8113 \\
LR chi2 & 336.25 & 515.86 & 325.52 & 393.63 & 395.12 \\
Prob > chi2 & 0.000 & 0.000 & 0.000 & 0.000 & 0.000 \\
Log likelihood & -951.55 & -1023.65 & -1112.64 & -1078.77 & -1089.31 \\
Pseudo R2 & 0.1502 & 0.2013 & 0.1276 & 0.1543 & 0.1535 \\
Efron's R2 & 0.057 & 0.105 & 0.05 & 0.068 & 0.065 \\
AIC & 1919.10 & 2065.29 & 2245.28 & 2181.55 & 2202.63 \\
BIC & 1974.28 & 2128.24 & 2315.24 & 2265.50 & 2286.64 \\
Failure & $0.00 \%$ & $1.33 \%$ & $0.34 \%$ & $0.67 \%$ & $0.33 \%$ \\
Non-Failure & $99.99 \%$ & $99.90 \%$ & $99.96 \%$ & $99.95 \%$ & $99.95 \%$ \\
Correctly Classified & $96.45 \%$ & $96.23 \%$ & $96.28 \%$ & $96.28 \%$ & $96.25 \%$ \\
\hline
\end{tabular}

Notes: We report the marginal effect of a change in the relevant independent variables in a probit regression model and the classification of models.

Z-statistics are in the parentheses. ${ }^{*}, *$ and $* * *$ indicate statistical significance at $10 \%, 5 \%, 1 \%$ level, respectively. All variables are described in Table 1.

\section{Conclusions}

Our motivation for this research is to show that bank failure in the US during the financial crisis of 2008 to 2010 was driven by the decisions management made affecting the risk profile of the bank. We analyze 31 variables that have been identified in the literature as being predictive of bank failure and based on the literature made a priori predictions regarding their influence on bank failure (see Table 1). We examine 29 of these variables using a univariate t-test for the difference of mean values at two times, the $4^{\text {th }}$ quarter of 2007 and the $4^{\text {th }}$ quarter of 2008 (two of the variables, home price index seasonal adjusted and growth of personal income were not included in this part of the analysis as they are unaffected by the banks' activities). Most of our hypotheses prove correct; however there are some surprises in the data (Tables $4,5, \& 6$ ). We believed that multifamily residential real estate loans to real estate loans and 1-4 family residential loans to real estate loans would not be associated with the likelihood of bank failure, but they prove to be positively and negatively correlated, respectively. Multifamily real estate loans prove to be risky during this period while 1-4 family residential loans reduce the risk of bank failure. Along this line, we believed that commercial real estate loans would be risky for banks, but they prove to be uncorrelated with bank failure. We also believed that off-balance sheet derivatives to total assets, interbank deposits to total deposits, real estate loans to total assets, and size would be associated with lower risk of bank failure but all of them except off-balance sheet derivatives are associated with higher risk of bank failure. Off-balance sheet derivatives are uncorrelated with the probability of bank failure.

Next, we test five probit regression models designed to model the risk associated with lending, detailed lending, liquidity and lending, lending and market trading, and lending and market trading as well as market conditions (Tables 4, 7, 8, \& 9). We find that after controlling for other risks, 1-4 family residential loans to real estate loans, net charge offs to average loans, real estate acquired through foreclosure to total assets, net gains on sales of loans to total non-interest income, loans to depository institutions to total assets, growth of total loans and leases and mortgage-backed securities to total assets are not significant risk factors, but that commercial and industrial loans to total assets and commercial real estate loans to real estate loans are negatively and positively related to the probability of bank failure, respectively.

We find that banks failed during the 2008 to 2010 financial crisis because of choices management made to accept more risk, specifically by having higher financial leverage, investing in higher risk loans in real estate and construction and by holding less liquid assets and fewer low risk loans like single family real estate loans. In the future both bank management and regulators need to be cognizant of these risk factors in order to avoid financial distress that may lead to institutional failure.

\section{References}

Abrams, B. A., \& Huang, C. J. (1987). Predicting Bank Failures: The Role of Structure in Affecting. Applied Economics, 19(10), 1291-1302. https://doi.org/10.1080/00036848700000117

Acharya, V. V., \& Viswanathan, S. (2011). Leverage, Moral Hazard, and Liquidity. Journal of Finance, 66(1), 99-138. https://doi.org/10.1111/j.1540-6261.2010.01627.x

Adrian, T., \& Shin, H. S. (2009). Money, Liquidity, and Monetary Policy (SSRN Scholarly Paper No. ID 
1331004). Rochester, NY: Social Science Research Network. Retrieved from http://papers.ssrn.com/abstract $=1331004$

Battaglia, F., \& Mazzuca, M. (2014). Securitization and Italian banks' risk during the crisis. The Journal of Risk Finance, 15(4), 458-478. https://doi.org/10.1108/JRF-07-2014-0097

Brunnermeier, M. K., \& Pedersen, L. H. (2009). Market Liquidity and Funding Liquidity. Review of Financial Studies, 22(6), 2201-2238. https://doi.org/10.1093/rfs/hhn098

Cebenoyan, A. S., \& Strahan, P. E. (2004). Risk management, capital structure and lending at banks. Journal of Banking \& Finance, 28(1), 19-43. https://doi.org/10.1016/S0378-4266(02)00391-6

Cole, R. A., \& White, L. J. (2012). Déjà vu all over again: The causes of US commercial bank failures this time around. Journal of Financial Services Research, 42(1), 5-29. https://doi.org/10.1007/s10693-011-0116-9

Cole, Rebel A., \& Gunther, J. W. (1998). Predicting Bank Failures: A Comparison of On- and Off-Site Monitoring Systems. Journal of Financial Services Research, 13(2), 103-117. https://doi.org/10.1023/A:1007954718966

Curry, T. J., Elmer, P. J., \& Fissel, G. S. (2007). Equity market data, bank failures and market efficiency. Journal of Economics and Business, 59(6), 536-559. https://doi.org/10.1016/j.jeconbus.2007.02.002

Fahlenbrach, R., Prilmeier, R., \& Stulz, R. M. (2012). This Time Is the Same: Using Bank Performance in 1998 to Explain Bank Performance during the Recent Financial Crisis. The Journal of Finance, 67(6), 2139-2185. https://doi.org/10.1111/j.1540-6261.2012.01783.x

Fayman, A., \& He, L. T. (2011). Prepayment risk and bank performance. The Journal of Risk Finance, 12(1), 26-40. https://doi.org/10.1108/15265941111100058

Gorton, G. B., \& Souleles, S. N. (2007). The risks of financial institutions. (M. S. Carey \& R. M. Stulz, Eds.) (National Bureau of Economic Research). Chicago: University of Chicago Press. Retrieved from http://public.eblib.com/choice/publicfullrecord.aspx? $\mathrm{p}=408579$

Gunsel, N. (2010). Determinants of the timing of bank failure in North Cyprus. The Journal of Risk Finance, 11(1), 89-106. https://doi.org/10.1108/15265941011012705

Ioannidou, V. P., \& Penas, M. F. (2010). Deposit insurance and bank risk-taking: Evidence from internal loan ratings. Journal of Financial Intermediation, 19(1), 95-115. https://doi.org/10.1016/j.jfi.2009.01.002

Jin, J. Y., Kanagaretnam, K., \& Lobo, G. J. (2011). Ability of accounting and audit quality variables to predict bank failure during the financial crisis. Journal of Banking \& Finance, 35(11), 2811-2819. https://doi.org/10.1016/j.jbankfin.2011.03.005

Kolari, J., Glennon, D., Shin, H., \& Caputo, M. (2002). Predicting large US commercial bank failures. Journal of Economics and Business, 54(4), 361-387. https://doi.org/10.1016/S0148-6195(02)00089-9

Lane, W. R., Looney, S. W., \& Wansley, J. W. (1986). An application of the Cox proportional hazards model to bank failure. Journal of Banking \& Finance, 10(4), 511-531. https://doi.org/10.1016/S0378-4266(86)80003-6

Lucchetta, M. (2007). What Do Data Say About Monetary Policy, Bank Liquidity and Bank Risk Taking? Economic Notes, 36(2), 189-203. https://doi.org/10.1111/j.1468-0300.2007.00180.x

Martin, D. (1977). Early warning of bank failure: A logit regression approach. Journal of Banking \& Finance, 1(3), 249-276. https://doi.org/10.1016/0378-4266(77)90022-X

Meyer, P. A., \& Pifer, H. W. (1970). Prediction of bank failures. Journal of Finance, 853-868. https://doi.org/10.1111/j.1540-6261.1970.tb00558.x

Nier, E. W. (2005). Bank stability and transparency. Journal of Financial Stability, 1(3), $342-354$. https://doi.org/10.1016/j.jfs.2005.02.007

O’Brien, R. M. (2007). A Caution Regarding Rules of Thumb for Variance Inflation Factors. Quality \& Quantity 41(5). https://doi.org/10.1007/s11135-006-9018-6

Pettway, R. H., \& Sinkey, J. F. (1980). Establishing on-site bank examination priorities: An early-warning system using accounting and market information. Journal of Finance, 137-150. https://doi.org/10.1111/j.1540-6261.1980.tb03476.x

Secrist, H. (1938). National Bank Failures and Non-failures: An Autopsy and Diagnosis. Bloomington, Indiana: 
The Principia Press.

Shleifer, A., \& Vishny, R. W. (2010). Unstable banking. Journal of Financial Economics, 97(3), 306-318. https://doi.org/10.1016/j.jfineco.2009.10.007

Sinkey Jr, J. (1974). The way problem banks perform. The Bankers Magazine, 57(4), 40-51.

Sinkey Jr, J. F. (1975). A multivariate statistical analysis of the characteristics of problem banks. The Journal of Finance, 30(1), 21-36. https://doi.org/10.1111/j.1540-6261.1975.tb03158.x

Sinkey Jr, Joseph F. (1977). Identifying Large Problem/Failed Banks: The Case of Franklin National Bank of New York. Journal of Financial and Quantitative Analysis, 12(05), 779-800. https://doi.org/10.2307/2330256

Sinkey Jr, Joseph F. (1978). Identifying “Problem” Banks: How Do the Banking Authorities Measure a Bank's Risk Exposure? Journal of Money, Credit and Banking, 184-193.

Uzun, H., \& Webb, E. (2007). Securitization and risk: empirical evidence on US banks. The Journal of Risk Finance, 8(1), 11-23. https://doi.org/10.1108/15265940710721046

van Loon, E., \& de Haan, J. (2015). Location of banks and their credit ratings. Journal of Risk Finance (Emerald Group Publishing Limited), 16(3), 220-232. https://doi.org/10.1108/JRF-11-2014-0161

Wagner, W. (2007). The liquidity of bank assets and banking stability. Journal of Banking \& Finance, 31(1), 121-139. https://doi.org/10.1016/j.jbankfin.2005.07.019

Wheelock, D. C., \& Wilso, P. W. (2005). The Contribution of On-Site Examination Ratings to an Empirical Model of Bank Failures. Review of Accounting and Finance, 4(4), 110-133. https://doi.org/10.1108/eb043440

Wooldridge, J. M. (2005). Introductory Econometrics: A Modern Approach (3 edition). Mason, OH: Cengage Learning.

Yeh, Q.-J. (1996). The application of data envelopment analysis in conjunction with financial ratios for bank performance evaluation. Journal of the Operational Research Society, 980-988. https://doi.org/10.1057/jors.1996.125

\section{Copyrights}

Copyright for this article is retained by the author(s), with first publication rights granted to the journal.

This is an open-access article distributed under the terms and conditions of the Creative Commons Attribution license (http://creativecommons.org/licenses/by/4.0/). 